\title{
Variability of weed infestation of winter wheat cultivars in relation to tillage systems
}

\author{
Zmienność zachwaszczenia odmian pszenicy ozimej \\ w zależności od systemu uprawy roli
}

\author{
Ryszard Weber ${ }^{1}$, Tomasz Sekutowski ${ }^{1}$, Zygmunt Owsiak ${ }^{2}$
}

\begin{abstract}
Summary
The aim of this work was the evaluation of winter wheat secondary weed infestation occurring in spring depending on a tillage system and cultivar. The following research parameters were analyzed: factor I - soil tillage system: a) ploughing, b) reduced tillage cultivating, c) reduced tillage - disc harrow; factor II - winter wheat cultivar: a) Muszelka, b) Ostka Strzelecka, c) Kohelia, d) Satyna. Herbicide Maraton 375 SC was used in autumn at a dose of $4 \mathrm{l} /$ ha. Weed density was evaluated by counting number of weeds in spring, using square-frame method on the $0.25 \mathrm{~m}^{2}$. The sum of all individual weed species was analyzed on every treatment set up in 4 replicates during 3 years of studies. Log-linear analysis showed that during the first years of reduced tillage systems, the number of weed per area was significantly higher than in the conventional tillage system. Muszelka cultivar showed the most variable weed infestation in comparison to other winter wheat cultivars. The dominant weed, regardless of the winter wheat cultivar and tillage systems, was Viola arvensis. Moreover, ploughing or reduced tillage conditions were favorable for Fumaria officinalis. However, reduced tillage system, using disc harrow provided optimal conditions for growth of Lamium purpureum.
\end{abstract}

Key words: winter wheat; cultivars; cultivation systems; weed infestation

\section{Streszczenie}

Celem pracy była analiza intensywności wtórnego, wiosennego zachwaszczenia pszenicy w zależności od sposobu uprawy roli i odmiany. Analizowano następujące czynniki doświadczenia: czynnik I - systemy uprawy roli: a) uprawa płużna, b) uprawa bezorkowa wykonana kultywatorem, c) uprawa bezorkowa wykonana brona talerzową; czynnik II - odmiany pszenicy ozimej: a) Muszelka, b) Ostka Strzelecka, c) Kohelia, d) Satyna. Jesienią zastosowano herbicyd Maraton 375 S.C. w dawce 4 I/ha. Liczbę chwastów w każdym analizowanym obiekcie oceniano wiosną, losowo, metodą ramkową na powierzchni 0,25 $\mathrm{m}^{2} \mathrm{w}$ fazie krzewienia pszenicy ozimej. Na każdym obiekcie analizowano sumaryczne liczebności poszczególnych gatunków chwastów uzyskane z 4 powtórzeń w trzech latach badań. Analiza log-liniowa wykazała, że w pierwszych latach stosowania bezpłużnych systemów uprawy liczba chwastów na jednostce powierzchni była istotnie większa niż w uprawie konwencjonalnej. Odmiana Muszelka wykazywała największą zmienność zachwaszczenia $w$ badanych systemach uprawy $w$ porównaniu do pozostałych odmian. Chwastem dominującym niezależnie od odmiany pszenicy i systemu uprawy był Viola arvensis. W warunkach uprawy płużnej i kultywatorem o sztywnych łapach stwierdzono znaczne nasilenie Fumaria officinalis. Natomiast Lamium purpureum charakteryzował się dużą liczebnością jedynie w uprawie bezorkowej przy użyciu kultywatora.

Słowa kluczowe: pszenica ozima; odmiany; systemy uprawy; zachwaszczenie

\footnotetext{
Instytut Uprawy Nawożenia i Gleboznawstwa - Państwowy Instytut Badawczy

Zakład Herbologii i Technik Uprawy Roli

Orzechowa 61, 50-540 Wrocław

rweber@iung.pulawy.pl

${ }^{2}$ Uniwersytet Przyrodniczy we Wrocławiu

Instytut Inżynierii Rolniczej

Chełmońskiego 37/41, 51-630 Wrocław
} 


\section{Wstęp / Introduction}

Prawidłowo prowadzona ochrona roślin uprawnych jest podstawą uzyskania wysokich i dobrej jakości plonów. Stanowi ona jeden $\mathrm{z}$ najważniejszych elementów integrowanej produkcji. Kraje członkowskie Unii Europejskiej zostały zobowiązane do wprowadzenia integrowanej ochrony roślin w terminie do 1 stycznia 2014 roku. Jednym z głównych zaleceń integrowanej ochrony jest zminimalizowanie zagrożeń dla środowiska wynikających z użycia pestycydów, przez zachęcanie do stosowania niskich dawek środków chemicznych lub wprowadzanie metod biologicznych, uprawowych lub hodowlanych ograniczających choroby, szkodniki i zachwaszczenie roślin uprawnych (Korbas i Pruszyński 2008). W ramach integrowanej produkcji rolnej zaleca się również stosowanie bezpłużnych metod uprawy roli. Wieloletnie badania intensywnej konwencjonalnej uprawy wykazały znaczną redukcję substancji organicznej w wierzchniej warstwie gleby, ograniczenie bioróżnorodności mikroorganizmów glebowych oraz zwiększoną erozję wodną i wietrzną (Garcia-Torres 1999; Köller i Linke 2001). Bezpłużna uprawa roli ogranicza erozję wodną i wietrzną, stymuluje różnorodność biologiczną gleby, stabilizuje agregaty glebowe oraz podwyższa zawartość substancji organicznej i makroelementów w górnych warstwach gleby (Weber 2004). Badania wykazały, że w warunkach uprawy bezpłużnej, zwłaszcza siewu bezpośredniego, następuje zwiększone nasilenie chwastów wieloletnich, jednoliściennych i form wykazujących reakcję świetlną. Zwalczanie chwastów w konwencjonalnych i bezpłużnych systemach uprawy jest przede wszystkim wykonywane przy użyciu środków chemicznych. Jednak użycie herbicydów jako jedynego sposobu ograniczania zachwaszczenia prowadzi do poważnych problemów selekcji genotypów odpornych, zwłaszcza w mało zróżnicowanych płodozmianach zbożowych (Richter i wsp. 2002; Mace i wsp. 2007). W ramach integrowanej ochrony roślin zaleca się wprowadzanie zróżnicowanego zmianowania, zwalczanie chwastów przed siewem, dostosowanie terminu i gęstości siewu rośliny uprawnej oraz stosowanie odmian konkurencyjnych do istniejącej populacji chwastów (Lemerle i wsp. 2001; Rasmussen 2004; Olsen i wsp. 2005). Kształtowanie zagęszczenia łanu roślin uprawnych, czyli wykorzystanie ich potencjału konkurencyjnego, jest jednym z ważniejszych elementów wykorzystywanych w celu regulacji zachwaszczenia (Kaczmarek i wsp. 2011).

Celem pracy była analiza intensywności wtórnego, wiosennego zachwaszczenia pszenicy w zależności od sposobu uprawy roli i odmiany.

\section{Materiały i metody / Materials and methods}

Badania przeprowadzono w latach 2011-2013 na obszarze gminy Jelcz-Laskowice, na glebie kompleksu żytniego dobrego. Doświadczenie dwuczynnikowe założono po przedplonie - rzepak ozimy, metodą split-plot w 4 powtórzeniach, na glebie płowej - piasku gliniastym mocnym, zalegającym na glinie lekkiej. Analizowano następujące czynniki doświadczenia: czynnik I - systemy uprawy roli: a) uprawa płużna, b) uprawa bezorkowa wykonana kultywatorem, c) uprawa bezorkowa wykonana brona talerzową (tab. 1); czynnik II - odmiany pszenicy ozimej: a) Muszelka, b) Ostka Strzelecka, c) Kohelia, d) Satyna. Wymienione odmiany pszenicy ozimej różnią się znacznie pod względem jakości technologicznej ziarna i należą do najczęściej uprawianych na obszarze Dolnego Śląska (COBORU 2012). Jesienią, w celu zniszczenia chwastów zastosowano herbicyd Maraton 375 SC (substancje czynne: pendimetalina 22,7\% i izoproturon 11,4\%) w dawce 4 1/ha. Liczbę chwastów na każdym analizowanym obiekcie oceniano wiosną, losowo, metoda ramkową na powierzchni $0,25 \mathrm{~m}^{2} \mathrm{w}$ fazie krzewienia pszenicy ozimej. Na każdym obiekcie analizowano sumaryczne liczebności poszczególnych gatunków chwastów uzyskane z 4 powtórzeń w trzech latach badań.

Tabela 1. Systemy uprawy roli

Table 1. Tillage systems

\begin{tabular}{|c|c|}
\hline $\begin{array}{l}\text { Uprawa roli } \\
\text { Tillage system }\end{array}$ & Zabiegi uprawowe - Cultivation measures \\
\hline $\begin{array}{l}\text { Tradycyjna (płużna) } \\
\text { Conventional tillage }\end{array}$ & $\begin{array}{l}\text { uprawa pożniwna - gruber na głębokość } 15 \mathrm{~cm}+\text { wał strunowy } \\
\text { uprawa podstawowa - orka pługiem na głębokość } 25 \mathrm{~cm}+\text { brona } \\
\text { uprawa przedsiewna - agregat uprawowy (kultywator }+ \text { wał strunowy) } \\
\text { post-harvest cultivation }- \text { gruber at } 15 \mathrm{~cm}+\text { string roller } \\
\text { basic land preparation }- \text { ploughing to the depth of } 25 \mathrm{~cm}+\text { harrow } \\
\text { pre-plant tillage }- \text { combined tillage unit (cultivator }+ \text { string roller) }\end{array}$ \\
\hline $\begin{array}{l}\text { Uproszczona } 1 \text { (uprawa bezorkowa) } \\
\text { Reduced tillage }\end{array}$ & $\begin{array}{l}\text { uprawa pożniwna - kultywator } \mathrm{z} \text { redlicami typu gęsiostopka } \\
\text { uprawa przedsiewna - agregat uprawowy (kultywator }+ \text { wał strunowy) } \\
\text { post-harvest cultivation }- \text { gruber at } 10 \mathrm{~cm}+\text { string roller } \\
\text { pre-plant tillage }- \text { combined tillage unit (cultivator }+ \text { string roller) }\end{array}$ \\
\hline $\begin{array}{l}\text { Uproszczona } 2 \text { (uprawa bezorkowa) } \\
\text { Reduced tillage }\end{array}$ & $\begin{array}{l}\text { uprawa pożniwna - brona talerzowa } \\
\text { uprawa przedsiewna - agregat uprawowy (kultywator }+ \text { wał strunowy) } \\
\text { post-harvest cultivation - disc harrow at } 15 \mathrm{~cm}+\text { string roller } \\
\text { pre-plant tillage }- \text { combined tillage unit (cultivator }+ \text { string roller) }\end{array}$ \\
\hline
\end{tabular}


Do analizy statystycznej wybrano 11 najczęściej występujących gatunków chwatów. Były to: Apera spicaventi L. (APESV), Elymus repens (L.) Gould. (ELYRE), Centaurea cyanus L. (CENCY), Brassica napus L. (BRSNA), Viola arvensis Murr. (VIOAR), Fumaria officinalis L. (FUMOF), Lamium purpureum L. (LAMPU), Stellaria media (L.) Vill. (STEME), Anthemis arvensis L. (ANTAR), Papaver rhoeas L. (PAPRH), Fallopia convolvulus (L.) A. Love (POLCO).

Współzależności między liczbą badanych gatunków chwastów na jednostce powierzchni, odmianami pszenicy i sposobem uprawy roli oceniano za pomocą analizy logliniowej. Istotne odchylenia liczebności chwastów oberwowanych od oczekiwanych wskazują w tej analizie na istnienie interakcji między badanymi zmiennymi. Po przekształceniu logarytmicznym wartości oczekiwanych model przyjmuje postać liniową, która w najprostszym przypadku może być przedstawiona wzorem:

$$
\operatorname{Ln}\left(\mathrm{E}_{\mathrm{ij}}\right)=\mathrm{M} .+\lambda_{\mathrm{i}}^{\mathrm{X}}+\lambda_{\mathrm{j}}^{\mathrm{Y}}+\lambda_{\mathrm{ij}}^{\mathrm{XY}}
$$

$\operatorname{Ln}\left(E_{\mathrm{ij}}\right)$ - logarytm naturalny wartości oczekiwanej,

M. - ogólna średnia oparta na równej liczebności w każdej komórce,

$\lambda_{i}^{X}-$ efekt i-tej wartości zmiennej $X$,

$\lambda_{\mathrm{j}}^{\mathrm{Y}}$ - efekt j-tej wartości zmiennej $\mathrm{Y}$,

$\lambda_{\mathrm{ij}}{ }^{\mathrm{XY}}$ - efekt interakcji i-tej wartości zmiennej $\mathrm{X}$ oraz j-tej wartości zmiennej Y.

Model log-liniowy pozwala na ocenę hipotezy, która zakłada brak interakcji dwóch lub więcej analizowanych czynników doświadczenia. Umożliwia również, po odrzuceniu nieistotnych współdziałan, ocenę wpływu poszczególnych czynników na zmienność badanych gatunków chwastów. W dalszej części opracowania badano strukturę zmienności liczebności gatunków chwastów w zależności od odmiany i sposobów uprawy roli. W tym celu zastosowano analizę korespondencji. Analiza korespondencji umożliwia ocenę struktury zależności odmian lub gatunków chwastów od pozostałych analizowanych czynników doświadczenia. Analiza ta przedstawia na dwuwymiarowym wykresie odmiany w powiązaniu $\mathrm{z}$ systemami uprawy $\mathrm{w}$ ten sposób, aby zachować naj- większy zakres zmienności badanych odmian z pierwotnej 11 wymiarowej przestrzeni (11 gatunków chwastów).

\section{Wyniki i dyskusja / Results and discussion}

Analizę optymalnego modelu statystycznego określającego wpływ systemu uprawy i odmian pszenicy ozimej na liczebność gatunków chwastów wykonano poprzez obliczenie wartości testu $\mathrm{Chi}^{2}$ dla efektów głównych oraz interakcji badanych czynników doświadczenia. Obliczone statystyki modelu z współdziałaniami drugiego i trzeciego rzędu są istotnymi wielkościami, dlatego hipotezę o braku zależności liczebności gatunków chwastów od systemu uprawy i odmiany pszenicy należy odrzucić na poziomie $\mathrm{p}<0,05$. Istotne wartości testu $\mathrm{Chi}^{2}$ wskazują, że włączenie do rozpatrywanego modelu interakcji poprawia jego dopasowanie. Ocenę istotności poszczególnych efektów głównych i ich interakcji przedstawia tabela 2 . Analiza wykazała znaczną zmienność liczebności badanych gatunków chwastów w zależności od systemów uprawy roli. Analizowana populacja chwastów odznaczała się również dużym zróżnicowaniem między poszczególnymi gatunkami. Świadczą o tym duże wartości statystyki $\mathrm{Chi}^{2}$. Nie stwierdzono natomiast istotnych różnic w liczbie badanych gatunków chwastów w poszczególnych odmianach pszenicy ozimej. Wyniki analizy log-liniowej wykazały także istotne interakcje pomiędzy gatunkami chwastów i odmianami, jak również między gatunkami chwastów a systemami uprawy roli. Można więc stwierdzić, że systemy uprawy roli istotnie różnicowały wielkość zachwaszczenia pszenicy ozimej. Wysokie wartości statystyki $\mathrm{Chi}^{2}$ dla interakcji odmian i gatunków chwastów, jak również odmian i systemów uprawy wskazują na istotny wpływ odmian na zmiany w liczebności badanych gatunków chwastów w poszczególnych wariantach upraw. Na podstawie tabeli 3. można stwierdzić, że w warunkach uprawy konwencjonalnej zachwaszczenie pszenicy niezależnie od odmiany było mniejsze w porównaniu do systemów uprawy bezpłużnej.

Tabela 2. Testy związku brzegowego i cząstkowego oraz interakcje między badanymi czynnikami doświadczenia Table 2. Tests of main effects, marginal and partial associations and interactions between experimental factors

\begin{tabular}{l|c|c|c|c|c}
\hline \multicolumn{1}{c|}{$\begin{array}{c}\text { Efekt } \\
\text { Effect }\end{array}$} & $\begin{array}{c}\text { Liczba } \\
\text { stopni } \\
\text { swobody } \\
\text { Degrees } \\
\text { of freedom }\end{array}$ & $\begin{array}{c}\text { Chi }{ }^{2} \text { związek } \\
\text { cząstkowy } \\
\text { Partial } \\
\text { association }\end{array}$ & $\begin{array}{c}\text { Istotność poziom } \\
\text { Significant } \\
\text { level } \\
\text { (p) }\end{array}$ & $\begin{array}{c}\text { Chi }{ }^{2} \text { związek } \\
\text { brzegowy } \\
\text { Marginal } \\
\text { Association }\end{array}$ & $\begin{array}{c}\text { Istotność } \\
\text { poziom } \\
\text { Significant } \\
\text { level } \\
\text { (p) }\end{array}$ \\
\hline $\begin{array}{l}\text { System uprawy } \\
\text { Tillage systems (1) }\end{array}$ & 2 & 159,69 & $<0,0001$ & 159,69 & $<0,0001$ \\
\hline $\begin{array}{l}\text { Odmiany } \\
\text { Cultivars (2) }\end{array}$ & 3 & 5,13 & 0,1622 & 5,13 & 0,1622 \\
\hline $\begin{array}{l}\text { Gatunki chwastów } \\
\text { Weed species (3) }\end{array}$ & 10 & 1091,74 & $<0,0001$ & 1091,74 & $<0,0001$ \\
\hline $1 \times 2$ & 6 & 82,98 & $<0,0001$ & 76,71 & $<0,0001$ \\
\hline $1 \times 3$ & 20 & 333,71 & $<0,0001$ & 327,45 & $<0,0001$ \\
\hline $2 \times 3$ & 30 & 143,19 & $<0,0001$ & 136,92 & $<0,0001$ \\
\hline
\end{tabular}


Tabela 3. Liczebności gatunków chwastów w zależności od systemu uprawy

Table 3. Marginal frequencies of weed species in relation to tillage systems

\begin{tabular}{|c|c|c|c|c|c|}
\hline \multirow{3}{*}{$\begin{array}{l}\text { Gatunki chwastów } \\
\text { Weed species }\end{array}$} & \multicolumn{4}{|c|}{ Uprawa płużna - Conventional tillage* } & \multirow{3}{*}{$\begin{array}{c}\text { Suma } \\
\text { Sum }\end{array}$} \\
\hline & \multicolumn{4}{|c|}{ odmiany - cultivars } & \\
\hline & Muszelka & Ostka Strzelecka & Kohelia & Satyna & \\
\hline APESV & 15 & 21 & 18 & 21 & 75 \\
\hline ELYRE & 0 & 3 & 0 & 3 & 6 \\
\hline CENCY & 27 & 12 & 24 & 27 & 90 \\
\hline BRSNA & 9 & 12 & 12 & 9 & 42 \\
\hline VIOLAR & 21 & 36 & 33 & 54 & 144 \\
\hline FUMOF & 0 & 54 & 24 & 24 & 102 \\
\hline LAMPU & 0 & 3 & 3 & 0 & 6 \\
\hline STEME & 15 & 24 & 24 & 21 & 84 \\
\hline ANTAR & 24 & 18 & 27 & 3 & 72 \\
\hline PAPRH & 0 & 18 & 24 & 21 & 63 \\
\hline POLCO & 0 & 3 & 3 & 3 & 9 \\
\hline \multirow[t]{2}{*}{ Suma - Sum } & 111 & 204 & 192 & 186 & 693 \\
\hline & \multicolumn{4}{|c|}{ Uprawa uproszczona 1 , gruber - Reduced tillage $1^{*}$} & \\
\hline APESV & 27 & 18 & 18 & 21 & 84 \\
\hline ELYRE & 9 & 3 & 6 & 6 & 24 \\
\hline CENCY & 33 & 15 & 18 & 18 & 84 \\
\hline BRSNA & 6 & 9 & 6 & 6 & 27 \\
\hline VIOLAR & 90 & 93 & 96 & 90 & 369 \\
\hline FUMOF & 108 & 12 & 6 & 12 & 138 \\
\hline LAMPU & 57 & 39 & 66 & 51 & 213 \\
\hline STEME & 18 & 15 & 12 & 15 & 60 \\
\hline ANTAR & 21 & 21 & 15 & 18 & 75 \\
\hline PAPRH & 30 & 24 & 12 & 21 & 87 \\
\hline POLCO & 0 & 6 & 3 & 0 & 9 \\
\hline \multirow[t]{2}{*}{ Suma - Sum } & 399 & 255 & 258 & 258 & 1170 \\
\hline & \multicolumn{4}{|c|}{ Uprawa uproszczona 2, brona talerzowa - Reduced tillage 2 disc harrow* } & \\
\hline APESV & 12 & 12 & 15 & 15 & 54 \\
\hline ELYRE & 6 & 3 & 6 & 6 & 21 \\
\hline CENCY & 15 & 15 & 30 & 18 & 78 \\
\hline BRSNA & 6 & 9 & 6 & 9 & 30 \\
\hline VIOLAR & 54 & 42 & 27 & 63 & 186 \\
\hline FUMOF & 15 & 12 & 12 & 12 & 51 \\
\hline LAMPU & 21 & 24 & 15 & 0 & 60 \\
\hline STEME & 12 & 15 & 15 & 9 & 51 \\
\hline ANTAR & 15 & 21 & 24 & 12 & 72 \\
\hline PAPRH & 18 & 9 & 12 & 21 & 60 \\
\hline POLCO & 3 & 30 & 6 & 6 & 45 \\
\hline Suma-Sum & 177 & 192 & 168 & 171 & 708 \\
\hline
\end{tabular}

*oznaczenia patrz tabela 1. - see Table 1

APESV - Apera spica-venti L., ELYRE - Elymus repens (L.) Gould., BRSNA - Brassica napus L, VIOAR - Viola arvensis Murr., LAMPU - Lamium purpureum L., STEME - Stellaria media (L.) Vill., ANTAR - Anthemis arvensis L., CAPBP - Capsella bursa-pastoris (L.) Med., CENCY - Centauea cyanus L, FUMOF - Fumaria officinalis L., PAPRH - Papaver rhoeas L., POLCO - Fallopia convolvulus (L.) A. Love

Gruber o sztywnych łapach wpłynął na zwiększenie populacji chwastów $\mathrm{w}$ porównaniu do efektu brony talerzowej. Odmiana Muszelka w uprawie płużnej w naj- większym stopniu ograniczała liczebność badanej populacji chwastów. Natomiast $\mathrm{w}$ uprawie bezpłużnej kultywatorem o sztywnych łapach odmiana ta przyczyniła 
się do istotnie większej liczby chwastów na jednostce powierzchni w porównaniu do pozostałych odmian. Chwastem dominującym niezależnie od odmiany pszenicy i systemu uprawy był Viola arvensis. W warunkach uprawy płużnej i kultywatorem o sztywnych łapach stwierdzono znaczne nasilenie Fumaria officinalis. Natomiast Lamium purpureum charakteryzował się dużą liczebnością jedynie w uprawie bezorkowej przy użyciu kultywatora.
Analizowane gatunki chwastów różniły się znacznie reakcją na systemy uprawy roli i odmiany pszenicy ozimej. Duże zmiany w liczebności chwastów w zależności od odmiany i uprawy roli stwierdzono u gatunków: F. officinalis, F. convolvulus i L. purpureum. Świadczą o tym duże odległości punktów reprezentujących te gatunki chwastów na wykresie analizy korespondencji (rys. 1). Brassica napus, Anthemis arvensis, Centaurea cyanus, Stellaria media i Apera spica-venti umiejscowione w bezpośrednim sąsiedztwie ćwiartki pierwszej wykresu

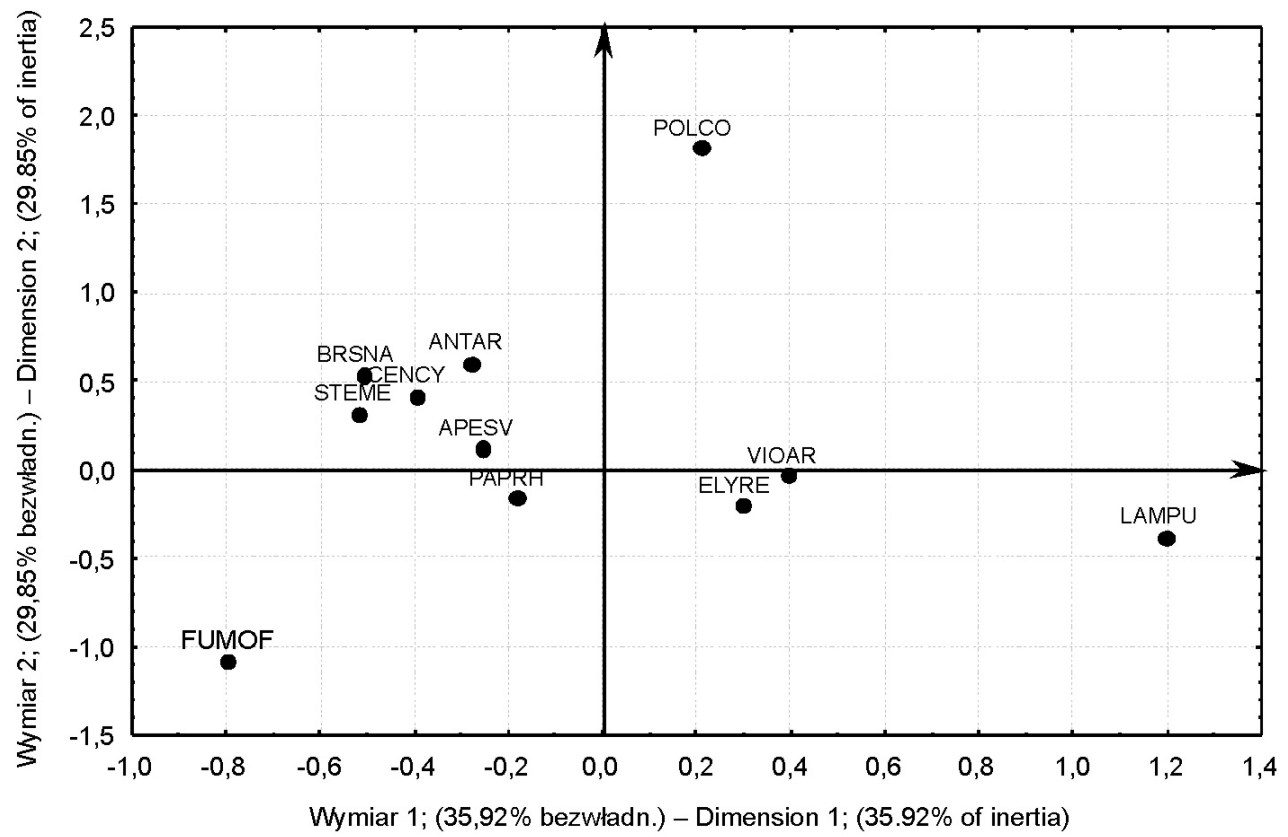

Rys. 1. Analiza korespondencji zmienności liczby chwastów w zależności od odmiany i systemu uprawy roli; oznaczenia patrz tabela 3.

Fig. 1. Correspondence analysis of variation of the number of weeds depending on the cultivar and tillage system; designation see Table 3.

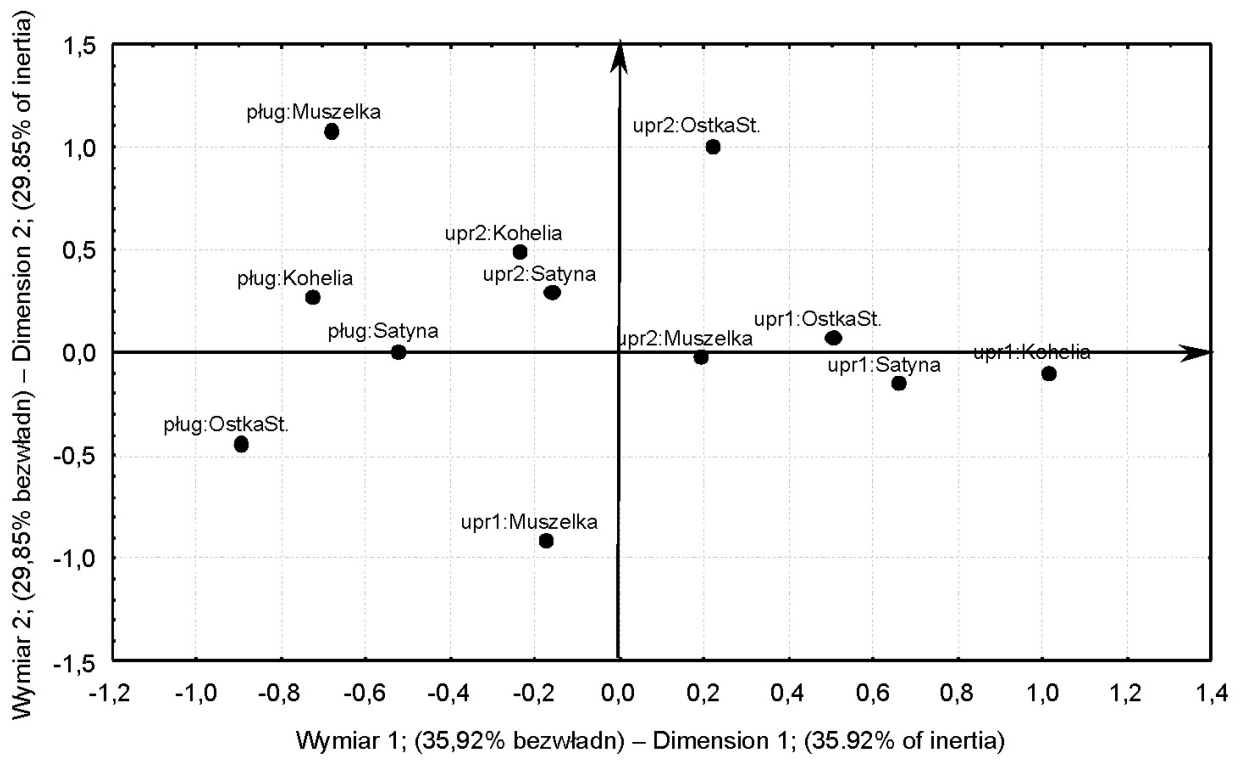

pług - uprawa płużna - conventional tillage

upr1 - uprawa uproszczona, kultywator - reduced tillage, gruber

upr2 - uprawa uproszczona, brona talerzowa - reduced tillage, disc harrow

Rys. 2. Analiza korespondencji zmienności odmian w zależności od liczby gatunków chwastów

Fig. 2. Correspondence analysis of variation of varieties depending on the number of weed species 
wskazują na małą zmienność nasilenia tych chwastów w zależności od uprawy i odmiany pszenicy ozimej. Odmiana Muszelka charakteryzowała się znacznym zróżnicowaniem zachwaszczenia w warunkach zmiennych systemów uprawy roli (rys. 2). Świadczą o tym duże odległości pomiędzy punktami (na wykresie) obrazującymi zmienność zachwaszczenia tej odmiany w różnych systemach uprawy. Odmiany Kohelia i Satyna w warunkach uprawy konwencjonalnej i bezpłużnej przy użyciu brony talerzowej odznaczały się małym zróżnicowaniem liczby analizowanych gatunków chwastów. Małą zmiennością zachwaszczenia cechowały się również odmiany: Ostka Strzelecka, Kochelta i Muszelka na obiektach uprawy bezorkowej wykonanej kultywatorem. Świadczy o tym bezpośrednie sąsiedztwo punktów odzwierciedlających zmienność zachwaszczenia tych odmian w uprawie bezpłużnej przy użyciu kultywatora o sztywnych łapach (rys. 2).

Przedstawione wyniki potwierdziły, że w warunkach upraw bezpłużnych następuje istotne zwiększenie zachwaszczenia plantacji, szczególnie w pierwszych latach wprowadzania tych systemów uprawy. Zwiększone zachwaszczenie w warunkach zróżnicowanych systemów uprawy bezpłużnej przyczyniło się do niższych plonów badanych odmian pszenicy ozimej w porównaniu do wyników uzyskanych w konwencjonalnym sposobie uprawy. Brak wydobycia nasion z głębszych warstw gleby w warunkach systemów bezorkowych może po kilku latach zmniejszyć presję chwastów w odniesieniu do tradycyjnej uprawy roli (Tørresen i wsp. 2003). Potwierdzają to badania Małeckiej i wsp. (2006), w których siew bezpośredni ograniczał występowanie chwastów w odniesieniu do tradycyjnej uprawy roli. Zachwaszczenie plantacji jest również $\mathrm{w}$ dużym stopniu uzależnione od intensywności bezpłużnych systemów uprawy. Gęstość chwastów jest najczęściej wyższa w wyniku stosowania aktywnych maszyn (brona aktywna, rototiller) w porównaniu do biernych agregatów uprawowych $\mathrm{z}$ broną talerzową lub zębatą (Ozipinar 2006). W prezentowanym opracowaniu na szczególną uwagę zasługuje istotna interakcja odmian systemami uprawy roli, która wykazała znaczne zróżnicowanie zachwaszczenia odmiany Muszelka w warunkach uprawy płużnej i kultywatorem o sztywnych łapach. Porównując wyniki analizy tych samych odmian w innych warunkach środowiskowych można wykazać znaczne różnice (pod względem zachwaszczenia) w ich reakcji na systemy uprawy roli (Weber i Gołębiowska 2013). Cechami szczególnymi, które wpływają na zdolność konkurencyjną odmian jest szybkie kiełkowanie i wzrost biomasy okrywowej, znaczna powierzchnia liści, zdolność krzewienia i przechwytywania światła (Buhler 2002). Jednak cechy te są w dużym stopniu uzależnione od temperatury oraz sumy opadów $\mathrm{W}$ poszczególnych miesiącach wegetacji roślin. Dużą rolę pod tym względem odgrywa również skład gatunkowy populacji chwastów oraz rodzaj i zasobność gleby w danym rejonie uprawy. Interakcja genotypowo-środowiskowa jest powszechnym zjawiskiem polegającym na niejednakowej reakcji odmian na zmienne warunki środowiskowe $\mathrm{w}$ miejscowościach, latach lub systemach uprawy (Romay i wsp. 2010). Wyniki badań wskazują również, że najważniejsze znaczenie w zdolności konkurencyjnej wobec chwastów przypisuje się cechom morfologicznym odmian zbóż, zwłaszcza ich wysokości (Torres i Fround-Williams 2002). Zróżnicowana konkurencyjność odmian w stosunku do chwastów może również wynikać $\mathrm{z}$ różnic $\mathrm{w}$ wielkości powierzchni liści w początkowych fazach ich rozwoju (Drews i wsp. 2009).

\section{Wnioski / Conclusions}

1. Analiza log-liniowa wykazała, że w pierwszych latach stosowania bezpłużnych systemów uprawy liczba chwastów na jednostce powierzchni była istotnie większa niż w uprawie konwencjonalnej.

2. Odmiana Muszelka wykazywała największą zmienność zachwaszczenia w badanych systemach uprawy w porównaniu do pozostałych odmian.

3. Chwastem dominującym niezależnie od odmiany pszenicy i systemu uprawy był $V$. arvensis. W warunkach uprawy płużnej i kultywatorem o sztywnych łapach stwierdzono znaczne nasilenie $F$. officinalis. L. purpureum charakteryzował się dużą liczebnością jedynie w uprawie bezorkowej przy użyciu kultywatora.

4. Zróżnicowanie gatunków chwastów i nasilenie Zachwaszczenia $\mathrm{w}$ uprawie określonych odmian pszenicy w dużym stopniu uzależnione jest od warunków środowiskowych uprawy.

Opracowanie wykonano $\mathrm{w}$ ramach zadania 2.6 w Programie Wieloletnim Instytutu Uprawy Nawożenia i Gleboznawstwa - Państwowego Instytutu Badawczego w Puławach.

\section{Literatura / References}

Buhler D.D. 2002. Challenges and opportunities for integrated weed management. Weed Sci. 50: 273-280.

Centralny Ośrodek Badania Roślin Uprawnych 2012. Lista opisowa odmian: 72-100.

Drews S., Neuhoff D., Köpke U. 2009. Weed suppression ability of three winter wheat varieties at different row spacing under organic framing conditions. Weed Res. 45 (5): 526-533.

Garcia-Torres L. (ed.). 1999. Konservierende Bodenbearbeitung in Europa: Umweltrelevante, ökonomische und EU politische Perspektiven. Deutsche Gesellschaft für Konservierende Bodenbearbeitung, Berlin: 5-23.

Kaczmarek S., Matysiak K., Kardasz P. 2011. Porównanie efektu stosowania mieszaniny tritosulfuronu z dikambą w pszenicy, jęczmieniu i owsie uprawianych w siewach czystych oraz mieszankach dwugatunkowych. Biul. IHAR 260/261: 163-172. 
Korbas M., Pruszyński S. 2008. Integrowana ochrona pszenicy. Inst. Ochr. Roślin - PIB, Poznań: 5-115.

Köller K., Linke Ch. 2001. Erfolgreicher Ackerbau ohne Pflug. DLG-Verl., Frankfurt am Main: 5-176.

Lemerle D., Gill G.S., Murphy C.E., Walker S.R., Cousens R.D., Mokhtari S., Pelzer S.J., Coleman R., Luckett D.J. 2001. Genetic improvement and agronomy for enhanced wheat competitiveness with weeds. Aust. J. Agric. Res. 52: 527-548.

Mace K., Morlon P., Munier-Jolain N.M., Quere L. 2007. Time scales as a factor in decision-making by French farmens on weed management in annual crops. Agric. Syst. 93: 115-142.

Małecka I., Blecharczyk A., Dobrzeniecki T. 2006. Zachwaszczenie zbóż ozimych w zależności od systemu uprawy roli. [Response of weed community in winter cereals to tillage system]. Prog. Plant Prot./Post. Ochr. Roślin 46 (2): 253-255.

Olsen J., Kristensen L., Weiner J., Giepentrog H.W. 2005. Increased density and spatial uniformity increase weed suppression by spring wheat. Weed Res. 45 (4): 316-321.

Ozipinar S. 2006. Effects of tillage systems on weed population and economics for winter wheat production under the Mediterranean dryland conditions. Soil Till. Res. 87: 1-8.

Rasmussen I.A. 2004. The effect of swing date, stale seedbed, row width and mechanical weed control on leeds and yields of organic winter wheat. Weed Res. 44 (1): 12-20.

Richter O., Zwerger P., Bottcher U. 2002. Modelling spatio-temporal dynamics of herbicide resistance. Weed Res. 42 (1): $52-64$.

Romay M.C., Malvar R.A., Campo L., Alvarez A., Moreno-Gonzàlez J., Ordàs A., Pedro R. 2010. Climatic and genotypic effects for grain yield in maize under stress conditions. Crop Sci. 50: 51-58.

Torres N.E., Fround-Williams R.J. 2002. Effect of winter wheat cultivars and seed rate on biological characteristics of naturally occurring weed flora. Weed Res. 42 (6): 417-428.

Tørresen K.S., Skuterud R., Tandsaether H.J., Hagemo M.B. 2003. Long-term experiments with reduced tillage in spring cereals. I Effects on weed flora, weed seedbank and grain yield. Crop Prot. 22: 185-200.

Weber R. 2004. Zmienność plonowania odmian pszenicy ozimej w zależności od przedplonu i sposobu uprawy roli. IUNG, Monografie i Rozprawy Naukowe 12: 5-88.

Weber R., Gołębiowska H. 2013. Zmienność zachwaszczenia nowych odmian pszenicy ozimej w zależności od sposobu uprawy roli. [Weed infestation variability of the new winter wheat cultivars depending on the tillage system]. Prog. Plant Prot./Post. Ochr. Roślin 53 (2): $310-315$. 